\title{
Fresh meat quality of pigs fed diets with different fatty acid profiles and supplemented with red wine solids
}

\author{
Pier Giorgio PEIRETTI ${ }^{1}$, Francesco GAI ${ }^{1}$, Alberto BRUGIAPAGLIA ${ }^{2}$, Pier Paolo MUSSA ${ }^{3}$, Giorgia MEINERI ${ }^{3 *}$
}

\begin{abstract}
Three groups of pigs were fed three different diets, namely a diet rich in saturated fatty acids (palm oil-based, $\mathrm{PO}$ ), a polyunsaturated fatty acid (PUFA)-rich diet (corn oil-based, CO), and a PUFA-rich diet (corn oil-based) supplemented with red wine solids (RWS), which was added to the diet (CO+RWS) in order to assess the protective effect on the oxidative status of the pork meat. The addition of corn oil favourably modulates the FAs profile of the backfat, and to a lesser extent of the intramuscular fat of semimembranosus muscle, without causing adverse effects on the meat quality or on its oxidative stability. Moreover, these parameters were not affected by the addition of the RWS in the CO+RWS diet.
\end{abstract}

Keywords: pig; meat quality; red wine solids; fatty acids.

Practical Application: The red wine solids supplementation in feed should provide a good protection of the meat from oxidation.

\section{Introduction}

In recent years, awareness of the importance of diet in human health has increased. During the last two decades, nutritionists have clearly identified selected foods that play an important role in maintaining the physical and mental health status of consumers. Beyond meeting nutritional needs, it is generally recognized that dietary factors are considered to modulate the detrimental development of certain chronic diseases (Anjum et al., 2013).

Regarding the lipid component of the diet, specific advice (Gibney, 1993) is to reduce the intake of saturated fatty acids (SFAs) and to increase the intake of polyunsaturated fatty acids (PUFAs). Numerous epidemiological and clinical studies have documented the nutritional benefits of PUFAs to prevent the incidence of cardiovascular diseases (Wijendran \& Hayes, 2004) and cancer pathogenesis (Larsson et al., 2004). In addition, the increased intake of PUFAs decreases serum cholesterol, which has a beneficial effect on blood pressure, skin diseases, diabetes, thrombosis, atherosclerosis, and hyperlipidemia (Yashodhara et al., 2009).

Diets rich in PUFAs have been shown to reduce plasma levels of low density lipoproteins (LDL), without decreasing high density lipoproteins (HDL), leading to a simultaneous decline of oxidized LDL (Noori et al., 2009; Stein et al., 2008).

In addition, the dietary introduction of PUFAs is very important during neonatal and aging periods (Noble \& Cocchi, 1989; Innis, 1991; Pénzes et al., 1993). As a result, there are increasing moves to enhance the levels of these fatty acids (FAs) in major human dietary components. Although it is the balance of FAs in the total diet that is physiologically important, attempts have been made to change many individual foods in line with the new dietary guidelines, to make them more attractive to consumers (Wood \& Enser, 1997). The FAs profile of the diet has been extensively examined in monogastric animal research, in view of the possibility of adjusting the FAs composition of animal meat and fat to produce healthier foods for human consumption (Averette Gatlin et al., 2003; Rentfrow et al., 2003).

As a large proportion of the saturated fat intake in Western society arises from animal fat, a greater degree of unsaturation of the pork meat lipid fraction is therefore expected to have a general positive impact on human health (Cardenia et al., 2011). The pork meat market has, in the past few years, been subjected to several changes influenced by consumer demands, which have addressed the production towards leaner and healthier meat. Special strategies have been undertaken to modify the lipid fraction of pork meat, which is known to greatly affect its overall quality. Lipid composition of pork meat varies depending on the muscle type and fibre, and it is influenced by many factors, such as animal genotype and feeding (Wood et al., 2004). Recently, swine feed has been formulated with a higher content of natural sources of PUFAs, such as $\mathrm{n}-3$ series or conjugated linoleic acid (CLA), due to human health concerns (Boselli et al., 2008).

Several researchers have studied the effect of diets supplemented with a high PUFAs content on fresh pork meat lipids. Diets enriched with vegetable oils (such as sunflower oil, soybean oil or corn oil) that contain an elevated PUFAs percentage should result in healthier products for consumers (Mitchaothai et al., 2007). Therefore, interests have been focused on supplementing diets with PUFAs to increase the tissue deposition of PUFAs and to improve the health status of meat consumers. 
Unfortunately, despite numerous scientific papers that describe the beneficial effects of PUFAs in the body, an increasing number of studies have clearly demonstrated the harmful effects of polyunsaturated fat in the diet on the oxidative status of animals (Ferguson \& Harris, 1999; Knudsen et al., 1993). In fact, PUFAs are the most vulnerable to the attack of free radicals, which induce lipid peroxidation. A diet containing linseed oil (rich in PUFAs), induced oxidative stress by significantly increasing not only the plasma malondialdehyde (MDA) concentration and urinary MDA excretion, but also by increasing the rate of leukocyte DNA damage in pigs (Rezar et al., 2003). Several human studies have also shown enhanced production of nitric oxide after dietary PUFAs supplementation. In fact, significant evidence of oxidative stress in vivo, caused by a high content of linoleic acid (LA, C18:2 n-6) in the diet, was observed in healthy subjects, despite their intake and plasma levels of antioxidants being within recommendations (Turpeinen et al., 1998).

In the case of animals, such as pigs, reared for the production of meat for human consumption, a greater degree of FAs unsaturation increases the susceptibility of fresh meat towards oxidation (Boselli et al., 2008). Lipid oxidation in meat products is mainly initiated in the highly unsaturated phospholipid fraction of cell membranes, which contain other unsaturated liposoluble molecules, such as cholesterol, which are also prone to oxidation (Boselli et al., 2005).

Furthermore, in fresh meat, PUFAs diet supplementation resulted in an undesirable flavour, an undesirable meat colour and nutrient loss due to peroxidation of these FAs (Byrne et al., 2001). Lipid oxidation is therefore the limiting factor for PUFAs to serve as nutritionally beneficial lipids in functional foods (Chaiyasit et al., 2007). However, the oxidative stability of muscle tissue also depends on the anti/pro-oxidant balance (Decker \& $\mathrm{Xu}, 1998$ ), so dietary supplementation with antioxidants might increase the oxidative stability of pork lipids (Boselli et al., 2008; Eder et al., 2005; Guo et al., 2006).

To counteract the oxidative processes in PUFAs-enriched meat, adequate protection must be implemented to ensure stable quality of fresh meat and a longer shelf-life of the meat. However, problems were found to arise when synthetic free radical scavengers, such as butylated hydroxyanisole, butylated hydroxytoluene, propyl gallate, and tertiary butylhydroquinone were involved, due to their potential deleterious effects on human health (Decker \& Mei, 1996). Thus, researchers have focused special attention on natural antioxidants that may be included in animal diets, as alternatives to minimize the use of synthetic food additives.

The scientific literature offers a wide range of examples of food and feed including antioxidant supplements, which resulted in a reduction of lipid peroxidation (O'Neill et al., 1999; Grau et al., 2001; Sáyago-Ayerdi et al., 2009). Recent studies have shown, for example, that the juice of red grapes contains antioxidant substances, which are considered as being effective in preventing chronic-degenerative diseases in humans and animals (Geleijnse et al., 2002; Lamont et al., 2012; Williamson \& Holst, 2008). Specific investigations carried out into red grapes and their juice have demonstrated that the antioxidant and anti-radical activity could be directly correlated with the complex matrix of polyphenols within the red grapes (Brenna \& Pagliarini, 2001; De Beer et al., 2003; Auger et al., 2004).

The high resistance against lipid oxidation of meat from animal fed red grape by products have been shown in poultry (Brenes et al., 2008; Smet et al., 2008), in rabbits (Choi et al., 2010), and in ruminants (Luciano et al., 2011; Rivas-Cañedo et al., 2013).

Furthermore, scientific research has correlated polyphenols, contained in plants used in the human diet, with a lower incidence of cardiovascular disease and inhibition of some types of cancer (Donaldson, 2004).

In this work, we intend to evaluate the possible effect of a red wine solids (RWS) obtained by freeze-drying organic red wine, which is alcohol-free and possesses a high content of phenolic compounds (Liofenol ${ }^{\mathrm{TM}}$ ). These antioxidants are not only beneficial due to their intrinsic properties, but can also safeguard PUFAs from possible peroxidation. The RWS chemical composition in terms of total polyphenols, anthocyanins, total flavonoids, proanthocyanidins and flavans, and its antioxidant power has been reported in a previous work by Peiretti et al. (2013). The RWS supplementation of the corn oil diet should provide a good protection of the meat from oxidation.

The aim of our study was to compare the effect on FAs profiles and the quality of fresh meat of three groups of pigs fed different diets, containing palm oil (rich in SFA), corn oil (rich in PUFAs) and corn oil supplemented with RWS, respectively. Assuming that the substitution of palm oil with corn oil in the diet could result in an increase of peroxidation products in fresh pork.

\section{Materials and methods}

\subsection{Animals and diets}

The study was carried out at the experimental piggery of the Department of Veterinary Sciences in Grugliasco (NW Italy). A total of 18 pigs belonging to the same genotype, aged 3 months, with a mean weight of $74 \mathrm{~kg}$, were randomly assigned to three different groups of six (three male and three female pigs each) with equal initial weight variability. Each group of animals was placed in a box of $2.3 \times 3 \mathrm{~m}$, under standard conditions at a temperature of $20 \pm 2{ }^{\circ} \mathrm{C}$, in an environment with artificial light and forced ventilation.

Three different diets were formulated (Table 1): a palm oil-based diet (PO), a corn oil-based diet (CO) and finally a corn oil-based diet supplemented with RWS (CO+RWS). Each mixed feed was stored in silos sheltered from light to avoid auto-oxidation of the lipid components, and the feed was offered ad libitum for the duration of the experiment (8 weeks).

Diet samples were analysed in duplicate for dry matter (DM; cod. 930.13), ash by ignition to $550{ }^{\circ} \mathrm{C}$, crude protein (CP; cod. 954.01) and ether extract (EE; cod. 945.16) according to the methods of the Association of Official Analytical Chemists (Association of Official Analytical Chemists, 1990). The gross energy (GE) was determined using an adiabatic bomb calorimeter (IKA C7000, Staufen, Germany). 
Table 1. Ingredients and chemical composition of the experimental diets (from Peiretti et al., 2013).

\begin{tabular}{|c|c|c|c|}
\hline & $\mathrm{PO}$ & $\mathrm{CO}$ & $\mathrm{CO}+\mathrm{RWS}$ \\
\hline \multicolumn{4}{|l|}{ Ingredients ( $\mathrm{g} / \mathrm{kg}$ as-fed basis) } \\
\hline Barley & 800 & 800 & 800 \\
\hline Soybean meal & 90 & 90 & 86.4 \\
\hline Wheat bran & 60 & 60 & 60 \\
\hline Palm oil & 30 & - & - \\
\hline Corn oil & - & 30 & 30 \\
\hline Red wine solids (RWS) & - & - & 3.6 \\
\hline Vitamin mineral premix ${ }^{(1)}$ & 17 & 17 & 17 \\
\hline Lysine & 3 & 3 & 3 \\
\hline \multicolumn{4}{|c|}{ Chemical composition ( $\mathrm{g} / \mathrm{kg}$ as-fed basis) } \\
\hline Dry matter & 891 & 911 & 890 \\
\hline Crude protein & 141 & 140 & 143 \\
\hline Ether extract & 42 & 46 & 47 \\
\hline Ash & 48 & 46 & 50 \\
\hline Gross energy, MJ/kg DM & 18.9 & 18.3 & 18.6 \\
\hline \multicolumn{4}{|c|}{$\begin{array}{l}\mathrm{PO}=\text { diet with palm oil; } \mathrm{CO}=\text { diet with corn oil; } \mathrm{CO}+\mathrm{RWS}=\text { diet with corn oil } \\
\text { supplemented with red wine solids (RWS). }{ }^{(1)} \text { Composition of the vitamin-mineral premix } \\
\text { (per kg of diet): vit. A } 312,000 \mathrm{IU} \text {; vit. D3 } 48,800 \mathrm{IU} \text {; } \alpha \text {-tocopheryl acetate } 68 \mathrm{mg} \text {; vit. } \\
\text { B1 } 39 \mathrm{mg} \text {; vit. B2 } 125 \mathrm{mg} \text {; vit. B6 } 39 \mathrm{mg} \text {; vit. B12 } 0.75 \mathrm{mg} \text {; vit. PP } 623 \mathrm{mg} \text {; biotin, } 0.75 \mathrm{mg} \text {; } \\
\text { choline chloride, } 12,500 \mathrm{mg} \text {; folic acid, } 40 \mathrm{mg} \text {; D-panthotenic acid } 500 \mathrm{mg} \text {; sodium } \\
\text { menadione bisulphate, } 25 \mathrm{mg} \text {; lysine, } 18,300 \mathrm{mg} \text {; Zn, } 275 \mathrm{mg} \text {; Fe, } 275 \mathrm{mg} \text {; Cu, } 25 \mathrm{mg} \text {; } \\
\text { Mn, } 17 \mathrm{mg} \text {; J, } 800 \mu \mathrm{g} \text {; Se, } 300 \mu \mathrm{\mu g} \text {. }\end{array}$} \\
\hline
\end{tabular}

\subsection{Slaughter procedures and sample collection}

At the end of the experiment, animals (mean live weight $117 \mathrm{~kg}$ ) were slaughtered in a commercial pig slaughterhouse according to industry-accepted procedures. The semimembranosus muscle (SM) and backfat (BF) were immediately removed from the left half-carcasses. SM muscle was divided into two parts. The fore part was used to measure water content, $\mathrm{pH}$, colour, shear force, drip and cooking losses. The hind part of the SM muscle was vacuum-packed, frozen at $-20{ }^{\circ} \mathrm{C}$ and then freeze dried (5Pascal, Trezzano sul Naviglio, Italy). Proximate composition, FAs profile and thiobarbituric-acid reactive substances (TBARS) values were determined on freeze-dried samples. BF samples were immediately vacuum-packed, frozen and stored at $-20^{\circ} \mathrm{C}$ for a week until gas chromatographic analysis.

\subsection{Fatty acid determination}

To determine FA composition, lipid extraction was performed on the diets, SM and BF samples, according to Peiretti \& Meineri (2008). The FAs content in the experimental diets was the mean of two replicates, and the FAs were analysed as methyl esters. Analysis was carried out by gas chromatography, using a Dani GC 1000 DPC (Dani Instruments S.P.A., Cologno Monzese, Italy), equipped with a fused silica capillary column - Supelcowax-10 $(60 \mathrm{~m} \times 0.32 \mathrm{~mm}$ (i.d.), $0.25 \mu \mathrm{m})$. The programmed temperature vaporizing (PTV) injection and flame ionization detector (FID) ports were set at $245^{\circ} \mathrm{C}$ and $270{ }^{\circ} \mathrm{C}$, respectively. The oven temperature programme was set at $50{ }^{\circ} \mathrm{C}$ for the first minute, increased at a rate of $5{ }^{\circ} \mathrm{C} / \mathrm{min}$ to $230{ }^{\circ} \mathrm{C}$, where it remained for $24 \mathrm{~min}$; the carrier gas was hydrogen. A volume of $1 \mu \mathrm{l}$ was injected using a Dani ALS 1000 auto sampler with a 1:50 split ratio. The peak area was measured using a Dani Data Station DDS
1000, and each peak was identified and quantified according to pure methyl ester standards (Restek Corporation, Bellefonte, PA, USA). The atherogenic (AI) and thrombogenic (TI) indexes of the fat (Equations 1 and 2) were calculated according to Ulbricht \& Southgate (1991) as follows:

$$
\begin{aligned}
& \mathrm{AI}=(\mathrm{C} 12: 0+4 \times \mathrm{C} 14: 0+\mathrm{C} 16: 0) / \\
& {[\Sigma \text { MUFA }+\Sigma(\mathrm{n}-6)+\Sigma(\mathrm{n}-3)]} \\
& \mathrm{TI}=(\mathrm{C} 14: 0+\mathrm{C} 16: 0+\mathrm{C} 18: 0) / \\
& {\left[\begin{array}{l}
0.5 \times \Sigma \text { MUFA }+0.5 \times \Sigma(\mathrm{n}-6)+ \\
3 \times \Sigma(\mathrm{n}-3)+\Sigma(\mathrm{n}-3) / \Sigma(\mathrm{n}-6)
\end{array}\right]}
\end{aligned}
$$

where MUFA is monounsaturated fatty acid. These indexes can indicate whether a food is suitable for the prevention of human cardiovascular diseases.

\section{4 pH measurement}

$\mathrm{pH}$ assessment in the SM muscle was performed at $45 \mathrm{~min}$ and $24 \mathrm{~h}$ after slaughter, using a Crison portable $\mathrm{pH}$-meter equipped with a spear tip electrode and an automatic temperature compensator probe (Crison Instruments, S.A., Alella, Spain).

\subsection{Colour measurement}

At 24 hours after slaughter, colour was evaluated by the CIELAB colour system. Lightness $\left(\mathrm{L}^{*}\right)$, redness $\left(\mathrm{a}^{*}\right)$ and yellowness $\left(\mathrm{b}^{*}\right)$ colour indexes were obtained in duplicate after $1 \mathrm{~h}$ of blooming at $4{ }^{\circ} \mathrm{C}$ with a Minolta CR331C Colorimeter (Minolta Camera Co., Japan) calibrated on D65 illuminant. Hue angle, which describes the fundamental colour of a substance, and Chroma, which describes the vividness of a colour, were calculated as $\tan ^{-1}$ $\left(b^{\star} / a^{*}\right)$ and $\left(a^{\star 2}+b^{\star 2}\right)^{0.5}$, respectively (Commission International de l'Eclairage, 1976).

\subsection{Drip loss measurements}

Drip losses were evaluated in 70 to $170 \mathrm{~g}$ samples. The samples were weighed, placed in a plastic container with a double bottom (Lundström \& Malmfors, 1985), refrigerated at $2-4{ }^{\circ} \mathrm{C}$ for $24 \mathrm{~h}$, and re-weighed. Drip losses were given as a percentage of the difference between the initial and the final sample weight.

\subsection{Cooking loss measurements}

To determine cooking losses, raw samples were individually weighed, vacuum packaged in a plastic bag and cooked in a water bath at $70{ }^{\circ} \mathrm{C}$ for $35 \mathrm{~min}$. Samples were then removed from the water bath, cooled under tap water, blotted and reweighed. Cooking losses were determined by calculating the weight difference in samples before and after cooking, expressed as a percentage of initial weight.

\subsection{Shear force measurement}

After the cooking loss measurements, the same samples were utilised in order to determine shear force. For each sample, 8 to 10 blocks of $1 \mathrm{~cm}^{2}$ cross-section area, cut parallel to the muscle fibre direction, were obtained. Shear force was employed 
to assess the texture characteristics of meat using an Instron 5543 universal testing machine (Instron Corporation, USA). Samples were sheared perpendicular to the fibre at $200 \mathrm{~mm} / \mathrm{min}$ crosshead speed.

\subsection{Proximate analyses}

Proximate analyses were carried out according to the methods of the Association of Official Analytical Chemists (Association of Official Analytical Chemists, 1990). Raw muscle samples were weighed, dried at $125{ }^{\circ} \mathrm{C}$ for $5 \mathrm{~h}$ and reweighed to determine the water content. Freeze dried samples were analysed to determine ash by ignition at $550{ }^{\circ} \mathrm{C}$ and ether extract (EE) using the Soxhlet method. Nitrogen was determined by the Kjeldahl method using a Buchi System apparatus (Buchi Labortechnik, Flawil, Switzerland). The crude protein was then calculated by multiplying $\mathrm{N} \times 6.25$.

\subsection{TBARS assay}

Lipid oxidation was determined on the freeze dried muscle. The TBARS assay was modified from that of Witte et al. (1970), and was performed for each meat sample in triplicate; $3 \mathrm{~g}$ of freeze-dried meat was homogenised for $30 \mathrm{sec}$ at high speed with $20 \mathrm{~mL}$ of $10 \%$ trichloroacetic acid using a Polytron tissue homogenizer (Type PT 10-35; Kinematica GmbH, Luzern, Switzerland). The supernatant was filtered through Whatman \#1 filter paper. A volume of $1 \mathrm{~mL}$ of filtrate was combined with $1 \mathrm{~mL}$ of a $0.02 \mathrm{M}$ aqueous 2-thiobarbituric acid solution (TBA), heated in a boiling water bath for $20 \mathrm{~min}$, together with a blank containing $1 \mathrm{~mL}$ of a TCA/water mix (1/1) and $1 \mathrm{~mL}$ of a TBA reagent, and subsequently cooled under running tap water. Samples were analysed in duplicate, and the results were expressed as mg of MDA per kilogram of freeze dried meat, using a standard curve that covered a concentration range of 1 to $10 \mathrm{mM} \mathrm{1,1,3,3-tetramethoxypropane} \mathrm{(Sigma-Aldrich,}$ Steinheim, Germany). The absorbance was measured at $532 \mathrm{~nm}$ with a Helios spectrophotometer (Unicam Limited, Cambridge, UK) against a blank that contained all the reagents, but no meat.

\subsection{Statistical analysis}

Statistical analyses were performed using the SPSS software package (version 11.5.1 for Windows, SPSS Inc., USA). Analysis of variance was used to evaluate the effect of diet on the FAs profiles of the SM and BF and meat quality traits. Differences were tested using Duncan's New Multiple Range Test. Results were considered as being statistically significant with $\mathrm{P}$ values of $<0.05$.

\section{Results and discussion}

\subsection{Composition and fatty acid profile of the diets}

Table 1 shows the ingredients and chemical composition of experimental diets (data previously reported by Peiretti et al., 2013). The three diets administered were isocaloric and isonitrogenous and differed in the lipid source: $\mathrm{PO}$ or $\mathrm{CO}$ and in the presence of the phytocomplex RWS in the CO+RWS diet. Previous studies carried out by our group (Peiretti et al., 2013) indicated that there were no statistically significant differences in final live weight, weight gain, and feed conversion rate between the three groups of pigs.

Table 2 illustrates the total lipids ( $\mathrm{g} / \mathrm{Kg}$ diet) and FAs contents ( $\mathrm{g} / 100 \mathrm{~g}$ of total FAs) of the experimental diets. The total lipid content is very similar between the three diets. Regarding the FAs, we can observe that myristic acid (C14:0) is only present, albeit at low quantities, in the PO diet; palmitic acid (PA, C16:0) and stearic acid (C18:0) are present in the PO diet in amounts approximately double compared to the $\mathrm{CO}$ and $\mathrm{CO}+\mathrm{RWS}$ diets: LA is instead present at much higher levels in diets containing CO. Other minor FAs have approximately similar values in all three diets.

\subsection{Fatty acid profile of the meat and backfat}

Table 3 shows the total lipid contents and the FAs composition in the SM muscle of pigs fed the three experimental diets. There are no statistically significant differences regarding the total lipid content and FAs profile between the groups, with the exception of $\mathrm{PA}$ and the atherogenic index, which are statistically higher in the $\mathrm{PO}$ group than the $\mathrm{CO}$ and $\mathrm{CO}+\mathrm{RWS}$ groups. Therefore addition of RWS in the CO+RWS group did not affect the intramuscular lipid composition when compared to the CO group.

Table 4 reports the total lipid contents and the FAs composition in the BF of pigs fed the experimental diets. The PO group resulted in a statistically significant greater percentage of oleic acid (C18:1 n-9) in adipose tissue compared to the CO and $\mathrm{CO}+\mathrm{RWS}$ groups; while the $\mathrm{CO}$ and $\mathrm{CO}+\mathrm{RWS}$ groups have a significantly higher content of LA than the PO group. As for all the essential FAs, LA cannot be synthesized by the body, and thus LA dietary levels have a great influence on tissue concentration of this FA (Wood \& Enser, 1997). LA is found mainly in soybean and corn oils; in fact, in our study, pigs fed diets containing $\mathrm{CO}$ have higher levels of LA than those fed the PO diet.

The total amount of MUFAs shows a significant difference in the PO group (higher values) with respect to the other two groups (lower values); the total amount of PUFAs shows a statistically significant difference between the $\mathrm{CO}$ and $\mathrm{CO}+\mathrm{RWS}$

Table 2. Fatty acid contents ( $\mathrm{g} / 100 \mathrm{~g}$ of total FAs) of the experimental diets.

\begin{tabular}{lrrc}
\hline & PO & CO & CO+RWS \\
\hline Lipid (g/kg) & 32.9 & 33.3 & 31.2 \\
C14:0 & 0.3 & 0.0 & 0.0 \\
C16:0 & 30.3 & 15.8 & 15.0 \\
C18:0 & 4.2 & 2.2 & 2.1 \\
C18:1n-9 & 28.7 & 25.3 & 24.4 \\
C18:1n-7 & 0.8 & 0.8 & 0.8 \\
C18:2n-6 & 32.2 & 52.1 & 54.0 \\
C18:3n-3 & 2.7 & 2.8 & 2.8 \\
C20:0 & 0.4 & 0.4 & 0.4 \\
C20:1n-9 & 0.4 & 0.5 & 0.4 \\
\hline
\end{tabular}

$\mathrm{PO}=$ diet with palm oil; $\mathrm{CO}=$ diet with corn oil; $\mathrm{CO}+\mathrm{RWS}=$ diet with corn oil supplemented with red wine solids (RWS). 
Table 3. Fatty acid composition (g/100g of total FAs; means \pm S.E.) in the semimembranosus muscle of pigs ( $n=6$ per group) fed the experimental diets.

\begin{tabular}{|c|c|c|c|}
\hline & $\mathrm{PO}$ & $\mathrm{CO}$ & $\mathrm{CO}+\mathrm{RWS}$ \\
\hline Lipid (g/kg) & $5.08 \pm 0.61$ & $5.66 \pm 1.10$ & $5.68 \pm 0.86$ \\
\hline C14:0 & $1.07 \pm 0.05$ & $0.97 \pm 0.06$ & $0.98 \pm 0.03$ \\
\hline C16:0 & $23.37^{\mathrm{a}} \pm 0.21$ & $22.45^{b} \pm 0.29$ & $22.65^{\mathrm{b}} \pm 0.14$ \\
\hline C16:1 & $2.85 \pm 0.29$ & $2.65 \pm 0.14$ & $2.55 \pm 0.18$ \\
\hline $\mathrm{C} 17: 0$ & $0.35 \pm 0.05$ & $0.23 \pm 0.02$ & $0.28 \pm 0.03$ \\
\hline C18:0 & $10.93 \pm 0.58$ & $10.53 \pm 0.19$ & $11.23 \pm 0.43$ \\
\hline C18:1n-9 & $44.58 \pm 1.02$ & $42.93 \pm 1.37$ & $42.73 \pm 0.67$ \\
\hline C18:1n-7 & $4.33 \pm 0.34$ & $4.22 \pm 0.10$ & $4.03 \pm 0.21$ \\
\hline C18:2n-6 & $9.65 \pm 1.15$ & $12.62 \pm 1.13$ & $12.35 \pm 0.78$ \\
\hline C18:3n-3 & $0.40 \pm 0.06$ & $0.37 \pm 0.03$ & $0.42 \pm 0.05$ \\
\hline C20:0 & $0.93 \pm 0.05$ & $0.80 \pm 0.05$ & $0.88 \pm 0.03$ \\
\hline C20:1n-9 & $0.45 \pm 0.04$ & $0.53 \pm 0.04$ & $0.53 \pm 0.03$ \\
\hline C20:4n-6 & $1.12 \pm 0.15$ & $1.72 \pm 0.54$ & $1.38 \pm 0.14$ \\
\hline $\mathrm{SFA}^{(1)}$ & $36.63 \pm 0.55$ & $34.95 \pm 0.42$ & $36.02 \pm 0.40$ \\
\hline MUFA $^{(2)}$ & $52.18 \pm 1.53$ & $50.33 \pm 1.58$ & $49.82 \pm 1.01$ \\
\hline PUFA $^{(3)}$ & $11.18 \pm 1.21$ & $14.72 \pm 1.61$ & $14.15 \pm 0.79$ \\
\hline PUFA n-3 ${ }^{(4)}$ & $0.40 \pm 0.06$ & $0.37 \pm 0.03$ & $0.42 \pm 0.05$ \\
\hline PUFA n- $6^{(5)}$ & $10.75 \pm 1.15$ & $14.32 \pm 1.60$ & $13.77 \pm 0.75$ \\
\hline$n-6 / n-3^{(6)}$ & $27.97 \pm 2.10$ & $39.46 \pm 5.32$ & $35.32 \pm 1.68$ \\
\hline Atherogenic Index & $0.45 a \pm 0.01$ & $0.42 b \pm 0.01$ & $0.43 b \pm 0.01$ \\
\hline Thrombogenic Index & $1.08 \pm 0.02$ & $1.01 \pm 0.02$ & $1.05 \pm 0.02$ \\
\hline \multicolumn{4}{|c|}{$\begin{array}{l}\mathrm{PO}=\text { diet with palm oil; } \mathrm{CO}=\text { diet with corn oil; } \mathrm{CO}+\mathrm{RWS}=\text { diet with corn oil } \\
\text { supplemented with red wine solids (RWS). } \mathrm{a} \text {-b Means in the same row with unlike } \\
\text { superscripts differ }(\mathrm{P}<0.05) \text {. }{ }^{(1)} \text { SFA: Saturated Fatty Acid. }{ }^{(2)} \text { MUFA: Monounsaturated } \\
\text { Fatty Acid. }{ }^{(3)} \text { PUFA: Polyunsaturated Fatty Acid. }{ }^{(4)} \text { PUFA n-3: Polyunsaturated Fatty } \\
\text { Acid series n-3. }{ }^{(5)} \text { PUFA n-6: Polyunsaturated Fatty Acid series n-6. }{ }^{(6)} \text { n-6/n-3: PUFA } \\
\text { n-6/ PUFA n-3 ratio. }\end{array}$} \\
\hline
\end{tabular}

groups (higher values) compared to the PO group (lower value). Within the family of PUFAs, PUFA n-3 levels are not significantly different between the three groups, while PUFA n- 6 levels are significantly lower in the PO group with respect to the $\mathrm{CO}$ and CO+RWS groups.

By analyzing the PUFA $n-6 / n-3$ ratio, there is a statistically significant difference between all three groups in the study: the $\mathrm{PO}$ group has the lowest value, the $\mathrm{CO}$ group has an intermediate value, and the $\mathrm{CO}+\mathrm{RWS}$ group presents the highest value. Bertol et al. (2013) have observed that in different body fat depots, there are changes in the PUFA n-6/n-3 ratio according to the different dietary oil supplementation.

The adipose tissue of pigs shows major differences in FAs composition between the various groups, compared to the muscles tissue (Leskanich et al., 1997; Rey et al., 2006). In monogastric animals, the FAs content in the muscular and adipose tissues reflects the FAs profile of the diet, as part of the ingested FAs is deposited directly into these tissues. This effect has been reported in several studies assessing different fat sources for finishing pigs (Apple et al., 2009; Benz et al., 2011; Enser et al., 2000; Juárez et al., 2010; Lauridsen et al., 1999; Olivares et al., 2009; Teye et al., 2006). Several studies have shown that the fat deposition in the tissues may be influenced by the degree of fat saturation of the diet (Averette Gatlin et al., 2003; Olivares et al., 2009).
Table 4. Fatty acid composition (g/100g of total FAs; means \pm S.E.) in the backfat of pigs ( $n=6$ per group) fed the experimental diets.

\begin{tabular}{|c|c|c|c|}
\hline & $\mathrm{PO}$ & $\mathrm{CO}$ & $\mathrm{CO}+\mathrm{RWS}$ \\
\hline Lipid (g/kg) & $65.40 \pm 3.90$ & $68.64 \pm 1.17$ & $67.42 \pm 0.93$ \\
\hline C14:0 & $0.90 \pm 0.05$ & $0.87 \pm 0.02$ & $0.85 \pm 0.04$ \\
\hline C16:0 & $21.90^{\mathrm{a}} \pm 0.49$ & $20.27^{b} \pm 0.29$ & $21.04^{\mathrm{ab}} \pm 0.41$ \\
\hline C16:1 & $1.67 \pm 0.18$ & $1.48 \pm 0.06$ & $1.31 \pm 0.10$ \\
\hline $\mathrm{C} 17: 0$ & $0.63^{\mathrm{a}} \pm 0.04$ & $0.48^{\mathrm{b}} \pm 0.05$ & $0.49^{b} \pm 0.03$ \\
\hline C18:0 & $11.62 \pm 0.81$ & $11.02 \pm 0.40$ & $12.69 \pm 0.45$ \\
\hline C18:1n-9 & $42.72^{\mathrm{a}} \pm 0.30$ & $39.40^{\mathrm{b}} \pm 0.29$ & $38.37^{\mathrm{b}} \pm 0.80$ \\
\hline C18:1n-7 & $2.65^{a} \pm 0.16$ & $2.37^{\mathrm{ab}} \pm 0.06$ & $2.17^{\mathrm{b}} \pm 0.07$ \\
\hline C18:2n-6 & $15.22^{\mathrm{b}} \pm 0.76$ & $21.22^{\mathrm{a}} \pm 0.44$ & $20.22^{\mathrm{a}} \pm 1.23$ \\
\hline C18:3n-3 & $0.77 \pm 0.03$ & $0.87 \pm 0.02$ & $0.78 \pm 0.05$ \\
\hline C20:0 & $0.90^{\mathrm{a}} \pm 0.04$ & $0.68^{\mathrm{b}} \pm 0.02$ & $0.80^{\mathrm{ab}} \pm 0.05$ \\
\hline C20:1n-9 & $0.73^{\mathrm{b}} \pm 0.04$ & $0.92^{\mathrm{a}} \pm 0.03$ & $0.92^{\mathrm{a}} \pm 0.04$ \\
\hline C20:4n-6 & $0.32 \pm 0.03$ & $0.37 \pm 0.02$ & $0.36 \pm 0.06$ \\
\hline $\mathrm{SFA}^{(1)}$ & $35.93 \pm 0.98$ & $33.35 \pm 0.63$ & $35.85 \pm 0.74$ \\
\hline MUFA $^{(2)}$ & $47.78^{a} \pm 0.56$ & $44.17^{\mathrm{b}} \pm 0.37$ & $42.80^{\mathrm{b}} \pm 0.84$ \\
\hline PUFA ${ }^{(3)}$ & $16.25^{\mathrm{b}} \pm 0.81$ & $22.48^{\mathrm{a}} \pm 0.48$ & $21.37^{\mathrm{a}} \pm 1.33$ \\
\hline PUFA n-3 ${ }^{(4)}$ & $0.77 \pm 0.03$ & $0.87 \pm 0.02$ & $0.78 \pm 0.05$ \\
\hline PUFA $n-6^{(5)}$ & $15.50^{\mathrm{b}} \pm 0.78$ & $21.60^{\mathrm{a}} \pm 0.45$ & $20.57^{\mathrm{a}} \pm 1.28$ \\
\hline$n-6 / n-3^{(6)}$ & $20.35^{c} \pm 0.22$ & $24.62^{\mathrm{b}} \pm 0.58$ & $26.42^{\mathrm{a}} \pm 0.32$ \\
\hline Atherogenic Index & $0.42 \pm 0.01$ & $0.38 \pm 0.01$ & $0.41 \pm 0.01$ \\
\hline Thrombogenic Index & $1.02 \pm 0.05$ & $0.91 \pm 0.03$ & $1.02 \pm 0.04$ \\
\hline \multicolumn{4}{|c|}{ 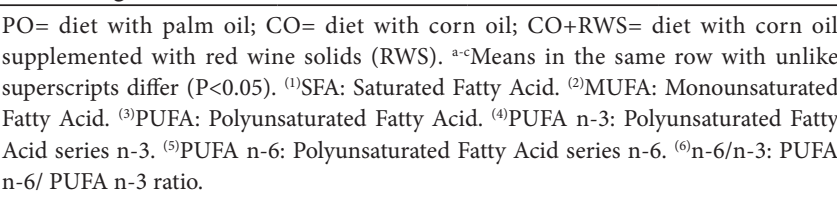 } \\
\hline
\end{tabular}

\subsection{Meat quality traits}

The SM muscle quality traits of pigs fed experimental diets are shown in Table 5. All parameters considered were not statistically different between the groups. In our study, we were aiming to determine whether the change in the FAs profile of the diets could have an influence on the quality characteristics of the meat. The substitution of SFAs with PUFAs in pig meat may have important implications for the quality of the meat, affecting the organoleptic characteristics, $\mathrm{pH}$, colour, and production of volatile compounds during the cooking of the meat (Apple et al., 2007; Wiseman et al., 2000). Some studies have reported that feeding highly unsaturated oil to pigs could negatively impact carcass fat for further processing due to the reduction of the fat melting point (Averette Gatlin et al., 2003; Rentfrow et al., 2003). Moreover, the flavour and odour of fresh pig meat may be negatively affected due to a high PUFAs content, as the meat is more susceptible to oxidation (Daza et al., 2005); on the other hand, a higher content of saturated fat can favour fat quality for processing due to its higher melting point and better oxidative stability (Bertol et al., 2013).

With regard to $\mathrm{pH}$, the different fat sources in the diet did not affect the meat $\mathrm{pH}$ values, and these results are in agreement with those obtained from previous studies (Bertol et al., 2013).

In relation to drip loss, the results obtained in our work are similar to those reported by Fraga et al. (2008). Schäfer et al. (2002) 
Table 5. Semimembranosus muscle traits (means \pm S.E.) of pigs ( $\mathrm{n}=6$ per group) fed experimental diets.

\begin{tabular}{lrrr}
\hline & \multicolumn{1}{c}{$\mathrm{PO}$} & \multicolumn{1}{c}{$\mathrm{CO}$} & \multicolumn{1}{c}{$\mathrm{CO}+\mathrm{RWS}$} \\
\hline $\mathrm{pH}_{45 \min }$ & $6.50 \pm 0.06$ & $6.42 \pm 0.07$ & $6.41 \pm 0.06$ \\
$\mathrm{pH}_{24 \mathrm{~h}}$ & $5.49 \pm 0.04$ & $5.54 \pm 0.05$ & $5.57 \pm 0.04$ \\
Lightness $\left(\mathrm{L}^{*}\right)$ & $48.70 \pm 1.15$ & $48.50 \pm 0.68$ & $49.26 \pm 0.45$ \\
Redness $\left(\mathrm{a}^{*}\right)$ & $20.50 \pm 0.67$ & $20.19 \pm 0.27$ & $19.47 \pm 0.27$ \\
Yellowness $\left(\mathrm{b}^{\star}\right)$ & $6.06 \pm 0.50$ & $4.74 \pm 0.26$ & $5.17 \pm 0.54$ \\
Chroma $\left(\mathrm{C}^{*}\right)$ & $21.45 \pm 0.62$ & $20.77 \pm 0.28$ & $20.82 \pm 0.27$ \\
Hue angle $\left(\mathrm{H}^{*}\right)$ & $16.59 \pm 1.57$ & $13.22 \pm 0.68$ & $14.79 \pm 1.53$ \\
Drip losses, \% & $7.00 \pm 0.45$ & $6.77 \pm 0.35$ & $6.72 \pm 0.29$ \\
Cooking losses, \% & $22.97 \pm 1.59$ & $24.87 \pm 0.37$ & $25.68 \pm 1.27$ \\
Shear force, $\mathrm{N}$ & $50.75 \pm 2.01$ & $53.70 \pm 2.40$ & $42.43 \pm 1.42$ \\
\hline PO= diet with palm oil; CO= diet with corn oil; CO+RWS= diet with corn oil and \\
supplemented with red wine solids (RWS).
\end{tabular}

reported drip losses in the range of 2.2 to $12.6 \%$. A higher level of drip losses is an indicator of a reduced quality of the meat, as meat that releases an excessive amount of liquid is less appreciated by consumers.

In this study, meat colour parameters were not significantly affected by diets. Several studies have shown that the colour parameters of pig meat were affected by the pigments present in the diet or by the oil supplementation. In the study by Joo et al. (2002), an alteration in the yellowness was determined by a modification of the FA composition of the muscle. In pork meat, Fraga et al. (2008) showed a decrease in redness and yellowness due to the addition of rice hulls to the diets, probably because of a decrease in food pigments resulting from the lower level of corn in the ration.

Cooking loss values observed in our study were slightly lower than the $32.3 \%$ reported by Hodgson et al. (1991), the $30.8 \%$ reported by Pires et al. (2002), and the $27.8 \%$ reported by Bridi et al. (2006). This is advantageous for the consumer as the meat was able to retain liquids during the cooking, and also tended not to withdrawn.

Shear force (SF) values obtained in our study ranged from 42.2 to 50.8 Newton, which were lower than those demonstrated by Morel et al. (2013). These authors reported, in the SM of pigs fed diets containing a blend of soybean and linseed oil, SF values ranging from 59.2 to 62.2 Newton. A high SF value is considered to be an index of poor meat quality, because, the greater the value, the lower the tenderness of the meat will be.

Data from Table 6 shows that there were no significant differences between groups regarding their chemical composition and oxidative status of SM muscle.

Chemical composition data are in agreement with the food composition tables for pork meat reported by the Italian Food Research Institute database (Marletta \& Carnovale, 2000).

In relation to the oxidative status of the muscle, TBARS ranged from 0.24 to $0.27 \mathrm{mg} \mathrm{MDA} / \mathrm{kg}$ meat. The mean TBARS values obtained were low across all the groups, which is certainly positive and protects the health of the consumer. Our study is in accordance with Miller et al. (1993), who reported that the meat
Table 6. Chemical composition (\% of freeze dried meat) and oxidative status (TBARS, mg malondialdehyde/kg freeze dried meat) (means \pm S.E.) of the semimembranosus muscle of pigs ( $n=6$ per group) fed experimental diets.

\begin{tabular}{lrrr}
\hline & \multicolumn{1}{c}{ PO } & \multicolumn{1}{c}{ CO } & \multicolumn{1}{c}{ CO+RWS } \\
\hline Water & $72.65 \pm 0.31$ & $72.92 \pm 0.38$ & $73.27 \pm 0.54$ \\
Ash & $4.47 \pm 0.10$ & $4.45 \pm 0.10$ & $4.34 \pm 0.13$ \\
Ether extract & $9.01 \pm 1.29$ & $9.23 \pm 1.83$ & $10.81 \pm 1.18$ \\
Crude protein & $86.47 \pm 0.27$ & $86.45 \pm 0.19$ & $84.93 \pm 0.17$ \\
TBARS & $0.24 \pm 0.02$ & $0.27 \pm 0.03$ & $0.24 \pm 0.04$ \\
\hline
\end{tabular}

$\mathrm{PO}=$ diet with palm oil; $\mathrm{CO}=$ diet with corn oil; $\mathrm{CO}+\mathrm{RWS}=$ diet with corn oil supplemented with red wine solids (RWS); TBARS = thiobarbituric-acid reactive substances.

of pigs fed $10 \%$ of animal fat, safflower oil, or sunflower oil did not differ in terms of the resulting TBARS values. Other authors, in previous tests performed on fresh pork found TBARS values equal to $0.50 \mathrm{mg} \mathrm{MDA} / \mathrm{kg}$ (Watanabe et al., 2010; Joo et al., 2002). In our work, the CO diet, even in the absence of RWS, did not produce a meat susceptible to premature oxidation. This could be explained to the fact that in our study, we used $\mathrm{CO}$, which contains a moderate amounts of vitamin $\mathrm{E}$. In fact it is known that the animal diets containing high levels of vitamin $\mathrm{E}$ or other antioxidants can reduce the lipid oxidation of the meat (Corino et al., 2008; Jensen et al., 1997). Indeed, the dietary vitamin $E$ clearly improved the oxidative stability of $n-3$ enriched lamb meat, as reported by Muíño et al. (2014).

Conversely, in the study by Rezar et al. (2003), the use of linseed oil introduced in the diets of pigs increased the meat oxidative stress, but in this case the oil contained very low amounts of vitamin $\mathrm{E}$. The oxidative stress in the groups of pigs fed linseed oil was additionally increased by the fact that the delivery of antioxidant supplements has not been increased. Diets containing high levels of PUFAs, such as of linseed oil, needed an antioxidant protection that could be achieved through the use of natural antioxidants. In fact, Zhang et al. (2015), have provided evidence that liquorice extract (LE), containing $16.4 \%$ total flavonoids, could be used as an attractive natural source of antioxidant additive in meat. The authors, evaluating the antioxidant ability of LE fed to sheep at different levels, demonstrated that dietary LE inclusion of 3000 to $4000 \mathrm{mg} / \mathrm{kg}$ feed increased total flavonoid, vitamin $\mathrm{E}$ and glutathione contents in meat. Moreover, LE improved free radical scavenging ability of meat, decreased malondialdehyde content and protected the meat against oxidation.

The possibility of using red wine solids as natural antioxidant in animals feeding was also investigated by Muíño et al. (2014). The authors found that red wine extract in the lamb diet lowered the $n-6 / n-3$ ratio of meat and did not improve lipid or protein stability, or sensory attributes of meat during the storage period. According to the authors, the lack of an effect of red wine extract on oxidative stability of lamb meat could arise from the use of a low dose ( $900 \mathrm{mg} / \mathrm{kg}$ feed), or due to a high level of n-3 fatty acids in the meat. 


\section{Conclusions}

The addition of corn oil, which is a good dietary source of lipids for pigs, as rich in PUFAs, favourably modulates the FAs profile of the BF, and to a lesser extent of the SM muscle, without causing adverse effects on fresh meat quality. The addition of antioxidants (RWS) to the CO+RWS diet compared to $\mathrm{CO}$ diet did not improve the muscle oxidative stability and did not affect the fresh meat quality. Further researches are needed to determine the optimum level of inclusion of polyphenols in pig diets rich on n-3 PUFAs with the aim to evaluate the storage of the meat subjected to different processing conditions and different time of storage.

\section{Acknowledgements}

Research was partially financed by the Ministero dell'Università e della Ricerca (Fondo ex-60\%). Thanks are due to Mr. G. Cerato (CISRA) for the preparation of the diets, Mr. R. Maritano (CISRA) for the care of the pigs, and Mr. Moriondo (the owner of "Salumificio Nadia", Arè di Caluso, Italy) for his expertise in the pork sampling; Dr. G. Perona (CISRA) and Mrs. C. Bianchi (Department of Veterinary Sciences, University of Torino) for their technical support, Azienda Agricola Ca'Novella (organic wine "Gocciorosso") who kindly provided Liofenol ${ }^{\mathrm{TM}}$ and Mrs. Srinivasan for the English revision of the manuscript.

\section{References}

Anjum, F. M., Haider, M. F., Khan, M. I., Sohaib, M., \& Arshad, M. S. (2013). Impact of extruded flaxseed meal supplemented diet on growth performance, oxidative stability and quality of broiler meat and meat products. Lipids in Health and Disease, 12(13), 1-12. http:// dx.doi.org/10.1186/1476-511X-12-13. PMid:23391137.

Apple, J. K., Maxwell, C. V., Galloway, D. L., Hamilton, C. R., \& Yancey, J. W. S. (2009). Interactive effects of dietary fat source and slaughter weight in growing-finishing swine: III. Carcass and fatty acid compositions. Journal of Animal Science, 87(4), 1441-1454. http:// dx.doi.org/10.2527/jas.2008-1455. PMid:19066247.

Apple, J. K., Maxwell, C. V., Sawyer, J. T., Kutz, B. R., Rakes, L. K., Davis, M. E., Johnson, Z. B., Carr, S. N., \& Armstrong, T. A. (2007). Interactive effect of ractopamine and dietary fat source on quality characteristics of fresh pork bellies. Journal of Animal Science, 85(10), 2682-2690. http://dx.doi.org/10.2527/jas.2007-0174. PMid:17609473.

Association of Official Analytical Chemists - AOAC. (1990). Official methods of analysis (15th ed.). Washington: AOAC.

Auger, C., Al-Awwadi, N., Bornet, A., Rouanet, J. M., Gasc, F., Cros, G., \& Teissedre, P. L. (2004). Catechins and procyanidins in Mediterranean diets. Food Research International, 37(3), 233-245. http://dx.doi. org/10.1016/j.foodres.2003.11.008.

Averette Gatlin, L., See, M. T., Hansen, J. A., \& Odle, J. (2003). Hydrogenated dietary fat improves pork quality of pigs from two lean genotypes. Journal of Animal Science, 81(8), 1989-1997. PMid:12926781.

Benz, J. M., Tokach, M. D., Dritz, S. S., Nelssen, J. L., DeRouchey, J. M., Sulabo, R. C., \& Goodband, R. D. (2011). Effects of choice white grease and soybean oil on growth performance, carcass characteristics, and carcass fat quality of growing-finishing pigs. Journal of Animal Science, 89(2), 404-413. http://dx.doi.org/10.2527/jas.2009-2737. PMid:21262976.
Bertol, T. M., Campos, R. M., Ludke, J. V., Terra, N. N., Figueiredo, E. A., Coldebella, A., Santos, J. I. Fo., Kawski, V. L., \& Lehr, N. M. (2013). Effects of genotype and dietary oil supplementation on performance, carcass traits, pork quality and fatty acid composition of backfat and intramuscular fat. Meat Science, 93(3), 507-516. http://dx.doi. org/10.1016/j.meatsci.2012.11.012. PMid:23273458.

Boselli, E., Caboni, M. F., Rodriguez-Estrada, M. T., Toschi, T. G., Daniel, M., \& Lercker, G. (2005). Photoxidation of cholesterol and lipids of turkey meat during storage under commercial retail conditions. Food Chemistry, 91(4), 705-713. http://dx.doi.org/10.1016/j. foodchem.2004.06.043.

Boselli, E., Pacetti, D., Lucci, P., Di Lecce, G., \& Frega, N. G. (2008). Supplementation with high-oleic sunflower oil and a-tocopheryl acetate: Effects on meat pork lipids. European Journal of Food Science and Technology, 110, 381-391.

Brenes, A., Viveros, A., Goñi, I., Centeno, C., Sáyago-Ayerdy, S. G., Arija, I., \& Saura-Calixto, F. (2008). Effect of grape pomace concentrate and vitamin E on digestibility of polyphenols and antioxidant activity in chickens. Poultry Science, 87(2), 307-316. http://dx.doi.org/10.3382/ ps.2007-00297. PMid:18212374.

Brenna, O. V., \& Pagliarini, E. (2001). Multivariate analysis of antioxidant power and polyphenolic composition in red wines. Journal of Agricultural and Food Chemistry, 49(10), 4841-4844. http://dx.doi. org/10.1021/jf0104376. PMid:11600032.

Bridi, A. M., Oliveira, A. R., Fonseca, N. A. N., Shimokomaki, M., Coutinho, L. L., \& Silva, C. A. (2006). Efeito do genótipo halotano, da ractopamina e do sexo do animal na qualidade da carne suína. Revista Brasileira de Zootecnia, 35(5), 2027-2033. http://dx.doi. org/10.1590/S1516-35982006000700021.

Byrne, D. V., Bredie, W. L. P., Bak, L. S., Bertelsen, G., Martens, H., \& Martens, M. (2001). Sensory and chemical analysis of cooked porcine meat patties in relation to warmed-over flavour and pre-slaughter stress. Meat Science, 59(3), 229-249. http://dx.doi.org/10.1016/ S0309-1740(01)00072-9. PMid:22062778.

Cardenia, V., Rodriguez-Estrada, M. T., Cumella, F., Sardi, L., Della Casa, G., \& Lercker, G. (2011). Oxidative stability of pork meat lipids as related to high-oleic sunflower oil and vitamin E diet supplementation and storage conditions. Meat Science, 88(2), 271-279. http://dx.doi. org/10.1016/j.meatsci.2010.12.034. PMid:21295921.

Chaiyasit, W., Elias, R. J., McClements, D. J., \& Decker, E. A. (2007). Role of physical structures in bulk oils on lipid oxidation. Critical Reviews in Food Science and Nutrition, 47(3), 299-317. http://dx.doi. org/10.1080/10408390600754248. PMid:17453926.

Choi, C. S., Chung, H. K., Choi, M. K., \& Kang, M. H. (2010). Effects of grape pomace on the antioxidant defense system in diet-induced hypercholesterolemic rabbits. Nutrition Research and Practice, 4(2), 114-120. http://dx.doi.org/10.4162/nrp.2010.4.2.114. PMid:20461199.

Commission International de l'Eclairage - CIE. (1976). Recommendations on uniform colour spaces-colour difference equations, psychometric colour terms (Supplement n. 2 to CIE publication n. 15). Paris: CIE.

Corino, C., Musella, M., \& Mourot, J. (2008). Influence of extruded linseed on growth, carcass composition, and meat quality of slaughtered pigs at one hundred ten and one hundred sixty kilograms of liveweight. Journal of Animal Science, 86(8), 1850-1860. http:// dx.doi.org/10.2527/jas.2007-0155. PMid:18441078.

Daza, A., Rey, A. I., Ruiz, J., \& Lopez-Bote, C. J. (2005). Effects of feeding in free-range conditions or in confinement with different dietary MUFA/PUFA ratios and $\alpha$-tocopheryl acetate, on antioxidants accumulation and oxidative stability in Iberian pigs. Meat Science, 
69(1), 151-163. http://dx.doi.org/10.1016/j.meatsci.2004.06.017. PMid:22062651.

De Beer, D., Joubert, E., Gelderblom, W. C., \& Manley, M. (2003). Antioxidant activity of South African red and white cultivar wines: free radical scavenging. Journal of Agricultural and Food Chemistry, 51(4), 902-909. http://dx.doi.org/10.1021/jf026011o. PMid:12568547.

Decker, E. A., \& Mei, L. (1996). Antioxidant mechanisms and applications in muscle foods. In Proceedings of the 49th Reciprocal Meat Conference, Provo.

Decker, E. A., \& Xu, Z. (1998). Minimizing rancidity in muscle foods. Food Technology, 52, 54-59.

Donaldson, M. S. (2004). Nutrition and cancer: a review of the evidence for an anti-cancer diet. Nutrition Journal, 3(19), 1-21. http://dx.doi. org/10.1186/1475-2891-3-19. PMid:15496224.

Eder, K., Müller, G., Kluge, H., Hirche, F., \& Brandsch, C. (2005). Concentrations of oxysterols in meat and meat products from pigs fed diets differing in the type of fat (palm oil or soybean oil) and vitamin E concentrations. Meat Science, 70(1), 15-23. http://dx.doi. org/10.1016/j.meatsci.2004.11.016. PMid:22063276.

Enser, M., Richardson, R. I., Wood, J. D., Gill, B. P., \& Sheard, P. R. (2000). Feeding linseed to increase the n-3 PUFA of pork: fatty acid composition of muscle, adipose tissue, liver and sausages. Meat Science, 55(2), 201-212. http://dx.doi.org/10.1016/S03091740(99)00144-8. PMid:22061086.

Ferguson, L. R., \& Harris, P. J. (1999). Protection against cancer by wheat bran: role of dietary fibre and phytochemicals. European Journal of Cancer Prevention, 8(1), 17-25. http://dx.doi.org/10.1097/00008469199902000-00003. PMid:10091039.

Fraga, A. L., Thomaz, M. C., Kronka, N. R., Budiño, F. E. L., Huaynate, R. A. R., \& Malheiros, E. B. (2008). Restrição alimentar qualitativa para suínos com elevado peso de abate. Revista Brasileira de Zootecnia, 37(5), 869-875. http://dx.doi.org/10.1590/S1516-35982008000500014.

Geleijnse, J. M., Launer, L. J., Van der Kuip, D. A., Hofman, A., \& Witteman, J. C. (2002). Inverse association of tea and flavonoid intakes with incident myocardial infarction: the Rotterdam Study. The American Journal of Clinical Nutrition, 75(5), 880-886. PMid:11976162.

Gibney, M. J. (1993). Fat in animal products: facts and perceptions. In J. D. Wood \& T. L. J. Lawrence (Eds.), Safety and quality of food from animals (Occasional Publication n. 17, pp. 57-61). Edinburgh: British Society of Animal Production.

Grau, A., Guardiola, F., Grimpa, S., Barroeta, A. C., \& Codony, R. (2001). Oxidative stability of dark chicken meat through frozen storage: influence of dietary fat and $\alpha$-tocopherol and ascorbic acid supplementation. Poultry Science, 80(11), 1630-1642. http://dx.doi. org/10.1093/ps/80.11.1630. PMid:11732681.

Guo, Q., Richert, B. T., Burgess, J. R., Webel, D. M., Orr, D. E., Blair, M., Fitzner, G. E., Hall, D. D., Grant, A. L., \& Gerrard, D. E. (2006). Effects of dietary vitamin $\mathrm{E}$ and fat supplementation on pork quality. Journal of Animal Science, 84(11), 3089-3099. http://dx.doi. org/10.2527/jas.2005-456. PMid:17032803.

Hodgson, R. R., Davis, G. W., Smith, G. C., Savell, J. W., \& Cross, H. R. (1991). Relationships between pork loin palatability traits and physical characteristics of cooked chops. Journal of Animal Science, 69(12), 4858-4865. PMid:1808180.

Innis, S. M. (1991). Essential fatty acids in growth and development. Progress in Lipid Research, 30(1), 39-103. http://dx.doi.org/10.1016/01637827(91)90006-Q. PMid:1771170.
Jensen, M. S., Jensen, S. K., \& Jakobsen, K. (1997). Development of digestive enzymes in pigs with emphasis on lipolytic activity in the stomach and pancreas. Journal of Animal Science, 75(2), 437-445. PMid:9051467.

Joo, S. T., Lee, J. I., Ha, Y. L., \& Park, G. B. (2002). Effects of dietary conjugated linoleic acid on fatty acid composition, lipid oxidation, color, and water-holding capacity of pork loin. Journal of Animal Science, 80(1), 108-112. PMid:11831506.

Juárez, M., Dugan, M. E. R., Aldai, N., Aalhus, J. L., Patience, J. F., Zijlstra, R. T., \& Beaulieu, A. D. (2010). Feeding co-extruded flaxseed to pigs: effects of duration and feeding level on growth performance and backfat fatty acid composition of grower-finisher pigs. Meat Science, 84(3), 578-584. http://dx.doi.org/10.1016/j.meatsci.2009.10.015. PMid:20374827.

Knudsen, K. E. B., Jensen, B. B., \& Hansen, I. (1993). Digestion of polysaccharides and other major components in the small and large intestine of pigs fed on diets consisting of oat fractions rich in $\beta$-D-glucan. The British Journal of Nutrition, 70(2), 537-556. http:// dx.doi.org/10.1079/BJN19930147. PMid:8260480.

Lamont, K., Blackhurst, D., Albertyn, Z., Marais, D., \& Lecour, S. (2012). Lowering the alcohol content of red wine does not alter its cardioprotective properties. South African Medical Journal, 102(6), 565-567. PMid:22668965.

Larsson, S. C., Kumlin, M., Ingelman-Sundberg, M., \& Wolk, A. (2004). Dietary long-chain n-3 fatty acids for the prevention of cancer: a review of potential mechanisms. The American Journal of Clinical Nutrition, 79(6), 935-945. PMid:15159222.

Lauridsen, C., Nielsen, J. H., Henckel, P., \& Sørensen, M. T. (1999). Antioxidative and oxidative status in muscles of pigs fed rapeseed oil, vitamin E, and copper. Journal of Animal Science, 77(1), 105115. PMid:10064033.

Leskanich, C. O., Matthews, K. R., Warkup, C. C., Noble, R. C., \& Hazzledine, M. (1997). The effect of dietary oil containing (n-3) fatty acids on the fatty acid, physicochemical, and organoleptic characteristics of pig meat and fat. Journal of Animal Science, 75(3), 673-683. PMid:9078483.

Luciano, G., Vasta, V., Monahan, F. J., López-Andrés, P., Biondi, L., Lanza, M., \& Priolo, A. (2011). Antioxidant status, colour stability and myoglobin resistance to oxidation of longissimus dorsi muscle from lambs fed tannin-containing diet. Food Chemistry, 124(3), 1036-1042. http://dx.doi.org/10.1016/j.foodchem.2010.07.070.

Lundström, K., \& Malmfors, G. (1985). Variation in light scattering and water-holding capacity along the porcine Longissimus dorsi muscle. Meat Science, 15(4), 203-214. http://dx.doi.org/10.1016/03091740(85)90076-2. PMid:22054647.

Marletta, L., \& Carnovale, E. (2000). Tabelle di Composizione degli Alimenti. Milano: Istituto Nazionale di Ricerca per gli Alimenti e la Nutrizione.

Miller, M. F., Ahmed, P. O., Shackelford, S. D., Haydon, K. D., \& Reagan, J. O. (1993). Effects of feeding diets containing different fat supplements to swine on the visual properties and storage stability of low-fat sausage. Meat Science, 33(2), 231-244. http://dx.doi. org/10.1016/0309-1740(93)90061-L. PMid:22060100.

Mitchaothai, J., Yuangklang, C., Wittayakun, S., Vasupen, K., Wongsutthavas, S., Srenanul, P., Hovenier, R., Everts, H., \& Beynen, A. C. (2007). Effect of dietary fat type on meat quality and fatty acid composition of various tissues in growing-finishing swine. Meat Science, 76(1), 95101. http://dx.doi.org/10.1016/j.meatsci.2006.10.017. PMid:22064195. 
Morel, P. C. H., Leong, J., Nuijten, W. G. M., Purchas, R. W., \& Wilkinson, B. H. P. (2013). Effect of lipid type on growth performance, meat quality and the content of long chain n-3 fatty acids in pork meat. Meat Science, 95(2), 151-159. http://dx.doi.org/10.1016/j. meatsci.2013.04.047. PMid:23739265.

Muíño, I., Apeleo, E., de la Fuente, J., Pérez-Santaescolástica, C., RivasCañedo, A., Pérez, C., Díaz, M. T., Cañeque, V., \& Lauzurica, S. (2014). Effect of dietary supplementation with red wine extract or vitamin $\mathrm{E}$, in combination with linseed and fish oil, on lamb meat quality. Meat Science, 98(2), 116-123. http://dx.doi.org/10.1016/j. meatsci.2014.05.009. PMid:24927047.

Noble, R. C., \& Cocchi, M. (1989). The relationship between the supply and demand for essential polyunsaturated fatty acids during mammalian and avian embryonic development. Research and Development in Agriculture, 6, 65-69.

Noori, M., Darabi, M., Rahimipour, A., Rahbani, M., Abadi, N. A., Darabi, M., \& Ghatrehsamani, K. (2009). Fatty acid composition of HDL phospholipids and coronary artery disease. Journal of Clinical Lipidology, 3(1), 39-44. http://dx.doi.org/10.1016/j.jacl.2008.11.010. PMid:21291787.

O’Neill, L. M., Galvin, K., Morrissey, P. A., \& Buckley, D. J. (1999). Effect of carnosine, salt and dietary vitamin $\mathrm{E}$ on the oxidative stability of chicken meat. Meat Science, 52(1), 89-94. http://dx.doi.org/10.1016/ S0309-1740(98)00152-1. PMid:22062147.

Olivares, A., Daza, A., Rey, A. I., \& Lopez-Bote, C. J. (2009). Interactions between genotype, dietary fat saturation and vitamin A concentration on intramuscular fat content and fatty acid composition in pigs. Meat Science, 82(1), 6-12. http://dx.doi.org/10.1016/j.meatsci.2008.11.006. PMid:20416584.

Peiretti, P. G., \& Meineri, G. (2008). Effects on growth performance, carcass characteristics, and the fat and meat fatty acid profile of rabbits fed diets with chia (Salvia hispanica L.) seed supplements. Meat Science, 80(4), 1116-1121. http://dx.doi.org/10.1016/j. meatsci.2008.05.003. PMid:22063845.

Peiretti, P. G., Mussa, P. P., Forneris, G., Gai, F., \& Meineri, G. (2013). Performance and apparent digestibility of growing pigs fed diets with different fat sources and supplemented with organic red wine solids. Livestock Research for Rural Development, 25(10), 1-5.

Pénzes, L., Fischer, H. D., \& Noble, R. C. (1993). Some aspects on the relationship between lipids, neurotransmitters, and aging. Zeitschrift für Gerontologie und Geriatrie, 26(2), 65-69. PMid:8098888.

Pires, I. S. C., Rosado, G. P., \& Azeredo, R. M. C. (2002). Composição centesimal, perdas de peso e maciez do lombo (Longissimus dorsi) suíno submetido a diferentes tratamentos de congelamento e descongelamento. British Journal of Nutrition, 15, 163-172.

Rentfrow, G., Sauber, T. E., Allee, G. L., \& Berg, E. P. (2003). The influence of diets containing either conventional corn, conventional corn with choice white grease, high oil corn, or high oil high oleic corn on belly/bacon quality. Meat Science, 64(4), 459-466. http://dx.doi. org/10.1016/S0309-1740(02)00215-2. PMid:22063128.

Rey, A. I., Daza, A., López-Carrasco, C., \& López-Bote, C. J. (2006). Feeding Iberian pigs with acorns and grass in either free-range or confinement affects the carcass characteristics and fatty acids and tocopherols accumulation in Longissimus dorsi muscle and backfat. Meat Science, 73(1), 66-74. http://dx.doi.org/10.1016/j. meatsci.2005.10.018. PMid:22062055.

Rezar, V., Pajk, T., Marinšek Logar, R., Ješe Janezic, V., Salobir, K., Orešnik, A., \& Salobir, J. (2003). Wheat bran and oat bran effectively reduce oxidative stress induced by high-fat diets in pigs. Annals of Nutrition
\& Metabolism, 47(2), 78-84. http://dx.doi.org/10.1159/000069279. PMid:12652059.

Rivas-Cañedo, A., Apeleo, E., Muiño, I., Pérez, C., Lauzurica, S., PérezSantaescolástica, C., Díaz, M. T., Cañeque, V., \& de la Fuente, J. (2013). Effect of dietary supplementation with either red wine extract or vitamin E on the volatile profile of lamb meat fed with omega-3 sources. Meat Science, 93(2), 178-186. http://dx.doi.org/10.1016/j. meatsci.2012.08.017. PMid:23026739.

Sáyago-Ayerdi, S. G., Brenes, A., Viveros, A., \& Goñi, I. (2009). Antioxidative effect of dietary grape pomace concentrate on lipid oxidation of chilled and long-term frozen stored chicken patties. Meat Science, 83(3), 528-533. http://dx.doi.org/10.1016/j. meatsci.2009.06.038. PMid:20416664.

Schäfer, A., Rosenvold, K., Purslow, P. P., Andersen, H. J., \& Henckel, P. (2002). Physiological and structural events post mortem of importance for drip loss in pork. Meat Science, 61(4), 355-366. http://dx.doi. org/10.1016/S0309-1740(01)00205-4. PMid:22061063.

Smet, K., Raes, K., Huyghebaert, G., Haak, L., Arnouts, S., \& De Smet, S. (2008). Lipid and protein oxidation of broiler meat as influenced by dietary natural antioxidant supplementation. Poultry Science, 87(8), 1682-1688. http://dx.doi.org/10.3382/ps.2007-00384. PMid:18648067.

Stein, O., Dabach, Y., Ben-Naim, M., Halperin, G., \& Stein, Y. (2008). Effects of oleic acid and macrophage recruitment on cholesterol efflux in cell culture and in vivo. Nutrition, Metabolism, and Cardiovascular Diseases, 18(9), 596-601. http://dx.doi.org/10.1016/j. numecd.2007.06.001. PMid:18060750.

Teye, G. A., Sheard, P. R., Whittington, F. M., Nute, G. R., Stewart, A., \& Wood, J. D. (2006). Influence of dietary oils and protein level on pork quality. 1. Effects on muscle fatty acid composition, carcass, meat and eating quality. Meat Science, 73(1), 157-165. http://dx.doi. org/10.1016/j.meatsci.2005.11.010. PMid:22062065.

Turpeinen, A. M., Basu, S., \& Mutanen, M. (1998). A high linoleic acid diet increases oxidative stress in vivo and affects nitric oxide metabolism in humans. Prostaglandins, Leukotrienes, and Essential Fatty Acids, 59(3), 229-233. http://dx.doi.org/10.1016/S09523278(98)90067-9. PMid:9844997.

Ulbricht, T. L., \& Southgate, D. A. T. (1991). Coronary heart disease: seven dietary factors. Lancet, 338(8773), 985-992. http://dx.doi. org/10.1016/0140-6736(91)91846-M. PMid:1681350.

Watanabe, M. C., Thomaz, U. S., Ruiz, V. M., Santos, G. C. I., Masson, A. L., Fraga, L. A. F., Pascoal, R. A., Robles-Huaynate, S. Z., \& Silva, S. Z. (2010). Carcass characteristics and meat quality of heavy swine fed different citrus pulp levels. Arquivo Brasileiro de Medicina Veterinária e Zootecnia, 62(4), 921-929. http://dx.doi.org/10.1590/ S0102-09352010000400023.

Wijendran, V., \& Hayes, K. C. (2004). Dietary n-6 and n-3 fatty acid balance and cardiovascular health. Annual Review of Nutrition, 24(1), 597-615. http://dx.doi.org/10.1146/annurev.nutr.24.012003.132106. PMid:15189133.

Williamson, G., \& Holst, B. (2008). Dietary reference intake (DRI) value for dietary polyphenols: are we heading in the right direction? British Journal of Nutrition, 99(Suppl 3), S55-S58. http://dx.doi. org/10.1017/S0007114508006867. PMid:18598589.

Wiseman, J., Redshaw, M. S., Jagger, S., Nute, G. R., \& Wood, J. D. (2000). Influence of type and dietary rate of inclusion of oil on meat quality of finishing pigs. Animal Science (Penicuik, Scotland), 70, 307-315.

Witte, V. C., Krause, G. F., \& Bailey, M. E. (1970). A new extraction method for determining 2-thiobarbituric acid values for pork and 
beef during storage. Journal of Food Science, 35(5), 582-585. http:// dx.doi.org/10.1111/j.1365-2621.1970.tb04815.x.

Wood, J. D., \& Enser, M. (1997). Factors influencing fatty acids in meat and the role of antioxidants in improving meat quality. British Journal of Nutrition, 78(Suppl 1), S49-S60. http://dx.doi.org/10.1079/ BJN19970134. PMid:9292774.

Wood, J. D., Nute, G. R., Richardson, R. I., Whittington, F. M., Southwood, O., Plastow, G., Mansbridge, R., da Costa, N., \& Chang, K. C. (2004). Effects of breed, diet and muscle on fat deposition and eating quality in pigs. Meat Science, 67(4), 651-667. http://dx.doi.org/10.1016/j. meatsci.2004.01.007. PMid:22061815.
Yashodhara, B. M., Umakanth, S., Pappachan, J. M., Bhat, S. K., Kamath, R., \& Choo, B. H. (2009). Omega-3 fatty acids: a comprehensive review of their role in health and disease. Postgraduate Medical Journal, 85(1000), 84-90. http://dx.doi.org/10.1136/pgmj.2008.073338. PMid:19329703.

Zhang, Y., Luo, H., Liu, K., Jia, H., Chen, Y., \& Wang, Z. (2015). Antioxidant effects of liquorice (Glycyrrhiza uralensis) extract during aging of longissimus thoracis muscle in Tan sheep. Meat Science, 105, 38-45. http://dx.doi.org/10.1016/j.meatsci.2015.03.002. PMid:25771136. 